\title{
Formulation Of Blue Ocean Strategy Developing A Bamboo Small Business In Binjai City
}

\author{
Samrin $^{1}$, Hasrul Azwar Hasibuan ${ }^{2}$, Rahmat Hidayat ${ }^{3}$, Rusiadi $^{4 *}$ \\ Universitas Pembangunan Panca Budi \\ ${ }^{*}$ Corresponding author: \\ Email: rusiadi@dosen.pancabudi.ac.id
}

\begin{abstract}
The research objective is to analyze the Blue Oceans Strategy method approach to improve strategy development for the Small and Medium Bamboo Industry in Binjai City. Woven crafts are one of the most abundant businesses in the SME sector, both rattan and bamboo handicrafts have dominated the activities of SMEs in Binjai City. The woven crafts are spread in 5 (five) sub-districts in Binjai City. Their business has grown more than 15 years ago, they have participated in many exhibitions or workshops outside the city to national. The fluctuating development of woven crafts is due to the large demand for woven bamboo and rattan goods. The data processing and analysis method used was through a post-positivism research approach, namely qualitative research. The method of analysis in this study uses a Structural Equation Modeling (SEM) approach, in forming a strategy for developing SMEs and Bamboo cooperatives with the ocean strategy and blue ocean strategy models in Binjai City. The competitive strategy used by the Small and Medium Shell Industry in Binjai City at this time is to identify competitive factors in the industry which consist of product uniqueness, a touch of art, done in detail, proximity to sources of raw materials, strategic location, availability of labor, Creativity, Prices are not fixed on market prices, Can be used as souvenirs, Skills and skills of employees, Attractiveness and impact after participating in exhibitions, Sensitivity to market choices, Organizational commitment, Work environment, Availability of online order facilities, Experience and managerial skills, Product orders completed on time.
\end{abstract}

Keywords: Blue Ocean Strategy, Canvas Business, SME Performance, SME Policy

\section{INTRODUCTION}

The development of the number of SMEs in the 2018 period increased by 2.18 percent, from $48,779,151$ units in 2017 to $49,840,489$ units in 2018. The SME economic sector which has the largest proportion of business units is the sector (1) Agriculture, Livestock, Forestry and Fishery; (2) Trade, Hotel and Restaurant; (3) Processing Industry; (4) Transportation and Communication; and (5) services with the development of each sector recorded at 51.14 percent, 27.40 percent, 6.49 percent, 5.54 percent and 4.60 percent (Nunuy Nur Afiah, 2016).It is undeniable, small and medium industries (IKM) are economic pillars for a developing country like Indonesia. With the spirit of developing the creative economy through the creation of added value, it can answer the challenges of an environmentally friendly industry (Affif, 2012). Unfortunately, in the face of business changes, small and medium industry (IKM) players put forward the competitive side of each other in order to pursue business growth, compete for competitive advantage, compete for market share, and strive to create differentiation. So it is not uncommon for competition in the market between these business actors to bring the consequences of bankruptcy.Microeconomically, the existence of SMEs is very volatile, this can occur due to shifts in the business sector to keep up with the existing market share or because they have a capital structure that is not yet established, so the 'grow' and 'death' of MSEs are often very difficult to detect, but macroeconomically the development of SMEs always showing improvement. Judging from its role in GRDP, SMEs also continue to show strengthening.

Woven crafts are one of the most abundant businesses in the SME sector, both rattan and bamboo handicrafts have dominated the activities of SMEs in Binjai City. The woven crafts are spread in 5 (five) sub-districts in Binjai City. Their business has grown more than 15 years ago, they have participated in many exhibitions or workshops outside the city to national. The fluctuating development of woven crafts is due to the large demand for woven bamboo and rattan goods. The handicraft market has also gone out of town, such 
as Medan, Langkat, Deli Serdang, and other areas in North Sumatra. Although only a few handicrafts have penetrated the export market, such as bamboo furniture, which is still very small in population.

As noted by Kim and Moubourgne (2015) that business actors in an industry take various ways to cope with market changes by deliberately setting market boundaries to inhibit and minimize new business actors. This is done in order to protect the market share that has been achieved by business actors already in the industry. This action shows the existence of a situation of intense industrial competition which is termed a bloody ocean or red ocean (Kim and Moubourgne, 2015). Here the market space is getting fuller, the prospects for profit and business growth are also reduced, the goods produced have become commodities.

\section{LITERATURE REVIEW \\ Blue Ocean}

Blue ocean is an unexplored and clearly defined market space and the opportunity for the industry to grow is enormous and does not see the trade-off between cost and value as an option to develop a business. The trade-off here is that to improve quality will lead to a consequence of increasing prices charged to consumers. Blue ocean itself can be created outside or inside a pre-existing market by expanding the boundaries of the existing market so that it requires companies to see things beyond the boundaries that can still be achieved by Kim and Mauborgne (2015).

\section{Red Ocean}

The market is constantly changing as are the number of competitors, consumer preferences, technology, and so on in an industry. Therefore, market leaders try as much as possible to provide limits and barriers to their competitors. This situation is what is meant by the red ocean. Implementing this strategy further tightens the existing competition among business actors to beat each other so as to create a red ocean for business actors.

\section{Creating Value Innovation}

Value innovation is the first step of the blue ocean strategy and as a strategy that embraces the entire system of corporate activities. The existence of value innovation will require companies to direct the entire system towards the goal of achieving a leap in value for buyers and for the company itself. Meanwhile, the competition-based red ocean strategy assumes that the structural conditions are defined and companies are forced to compete in those conditions. This assumption is referred to as the "structuralist" or "determinism" environmental view (Kim and Mauborgne 2005).Based on the figure above, it can be seen that of the 108 companies, it was found that 86 percent of these initiatives were line extensions or extensions, namely major improvements in the existing red ocean. However, the initiative represents only 62 percent of total revenue and 39 percent of total profit. While the remaining 14 percent are initiatives aimed at creating blue oceans. This initiative was able to generate 38 percent of total revenue and 61 percent of total profit.

\section{Non-consumers in the formation of Blue Ocean Strategy}

One way to achieve a blue ocean is to challenge two things that are commonly applied to the red ocean, namely focusing on existing consumers and sharpening segmentation to accommodate differences on the part of buyers. To maximize the size of the blue ocean, companies must look at non-customers and develop what buyers generally value. There are three levels of non-consumers that can be turned into consumers. These three tiers differ in their relative distance to the market. The first level is the closest to the market. This group is people who make purchases of products out of necessity. When another product offers something they think is more suitable and appropriate, they will leave the industry, but if given a jump in value, they will not only stay, but also increase the frequency of their purchases and break down the huge latent demand. The second level is people who refuse to buy offers from the industry. They are buyers who see the industry's offerings as an option to satisfy a need, but they refuse to buy them. They feel the products offered are ineffective or out of their reach. In general, their needs are satisfied by other products or ignored.

\section{Strategy Canvas}

As noted by Kim and Mauborgne (2005) that the strategy canvas is a framework for action as well as a diagnosis for building a good blue ocean strategy. There are two functions of the strategy canvas that can 
be utilized, namely the strategy canvas that summarizes the current situation in a well-known market space, so that it can be used to understand where the competition is currently being poured out, understand what factors are being used as a competition arena in products, services, and delivery, as well as understanding what consumers get from competitive offerings in the marketplace. The strategy canvas produces three things, namely:

1) The strategy canvas shows the strategic profile of an industry by clearly describing the factors that affect competition among industry players.

2) The strategy canvas shows the strategic profile of the current and potential competitors, identifying those factors that are the investment venues for them strategically.

3) The strategy canvas shows the company's strategic profile (corporate value curve) which describes how the company invests in competitive factors and how the company invests in these factors in the future.

\section{Value Curve}

In their notes Kim and Mauborgne (2005) explain that the value curve is a basic component of a strategy canvas. The value curve is a graphic depiction of a company's relative performance with respect to competitive factors in the industry. Therefore, by using the strategy canvas, through its value curve, it can be seen graphically about the company's general strategic profile compared to other companies.

\section{Creating Blue Ocean Strategy}

In particular, Kim and Mauborgne (2005) find six basic approaches to reshaping market boundaries, referred to as the six-way framework. These six avenues challenge the six core assumptions that underlie strategy in many companies, which keep companies trapped in competing in the red ocean.

\section{METHODS}

Structural equation modeling (SEM) was used to analyze the data from this study. SEM is a statistical modeling technique that is highly cross-sectional, linear and general. Included in this SEM are factor analysis, path analysis and regression.

\section{DISCUSION}

CFA is a special form of factor analysis. CFA is used to assess the relationship of a number of independent variables with others. Factor analysis is a technique for combining questions or variables that can create new factors and combine goals to create new groups in a row. There are two types of testing in this stage, namely: Confirmatory Factor Analysis (CFA), namely measurement model and structural equation modeling (SEM). The CFA measurement model is directed to investigate the unidimensionality of the indicators that explain a factor or a latent variable. As in the CFA, SEM testing is also carried out with two kinds of tests, namely the model suitability test and the significant causality test through the regression coefficient test.

The analysis step to test the research model is carried out through three stages, namely: first: testing the conceptual model. If the test results on this conceptual model are unsatisfactory, then proceed with the second stage, namely by providing modification treatment to the developed model after paying attention to the modification index and support (justification) of the existing theory. Furthermore, if unsatisfactory results are obtained in the second stage, then the third stage is taken by eliminating or dropping variables that have a CR (Critical Ratio) value smaller than 1.96, because this variable is considered not to have the same dimensions as the other variables. to explain a latent variable Ferdinand, (2010:132). The loading factor or lambda value $(\chi)$ is used to assess the suitability, suitability or unidimensionality of the indicators that make up the dimensions or variables. To test the CFA of each variable against the overall model, whether it is satisfactory or not is guided by the goodness of fit criteria.

Tabel 1. Output SEM

\begin{tabular}{|l|l|l|l|}
\hline $\begin{array}{l}\text { Goodness of } \\
\text { Fit Indeks }\end{array}$ & Cut of Value & $\begin{array}{l}\text { Hasil } \\
\text { Analisis }\end{array}$ & $\begin{array}{l}\text { Evaluasi } \\
\text { Model }\end{array}$ \\
\hline
\end{tabular}




\begin{tabular}{|c|c|c|c|}
\hline $\begin{array}{l}\text { Min fit } \\
\text { function of } \\
\text { chi-square }\end{array}$ & $\mathrm{p}>0,05$ & $(\mathrm{P}=0,000)$ & Moderafit \\
\hline Chisquare & $\begin{array}{l}\text { Carmines \& Melver }(1981) \\
\text { Df }=164=129.69\end{array}$ & 1354.68 & Fit \\
\hline $\begin{array}{l}\text { Non } \\
\text { Centrality } \\
\text { Parameter } \\
(\mathrm{NCP})\end{array}$ & $\begin{array}{l}\text { Penyimpangan sample cov } \\
\text { matrix dan fitted kecil }<\text { Chisquare }\end{array}$ & 471,797 & Fit \\
\hline $\begin{array}{l}\text { Root Mean } \\
\text { Square Error } \\
\text { of Approx } \\
\text { (RMSEA) }\end{array}$ & $\begin{array}{l}\text { Browne dan Cudeck (1993) } \\
<0,08\end{array}$ & 0.267 & Fit \\
\hline Model AIC & $\begin{array}{l}\text { Model AIC >Saturated } \\
<\text { Independence AIC }\end{array}$ & $\begin{array}{ll}625,797>\text { Saturated } & \text { AIC } \\
(240) & \\
<\text { Independence } & \text { AIC } \\
(1701,242) & \end{array}$ & Fit \\
\hline Model CAIC & $\begin{array}{l}\text { Model CAIC }<<\text { Saturated CAIC } \\
<\text { Independence CAIC }\end{array}$ & $\begin{array}{ll}773,760<\text { Saturated } & \text { CAIC } \\
(762,223) & \\
<\text { Independence } & \text { CAIC } \\
(1766,519) & \end{array}$ & Fit \\
\hline $\begin{array}{l}\text { Normed Fit } \\
\text { Index (NFI) }\end{array}$ & $>0,90$ & 0.666 & Moderafit \\
\hline $\begin{array}{l}\text { Parsimoni } \\
\text { Normed Fit } \\
\text { Index (PNFI) } \\
\end{array}$ & $0,60-0,90$ & 0.546 & Moderafit \\
\hline $\begin{array}{l}\text { Parsimoni } \\
\text { Comparative } \\
\text { Fit Index } \\
(\mathrm{PCFI}) \\
\end{array}$ & $0,60-0,90$ & 0.572 & Moderafit \\
\hline PRATIO & $0,60-0,90$ & 0.819 & Fit \\
\hline $\begin{array}{l}\text { Comparative } \\
\text { Fit Index } \\
(\mathrm{CFI})\end{array}$ & $\begin{array}{l}>0,90 \\
(\text { Bentler }(2000)\end{array}$ & 0.699 & Moderafit \\
\hline $\begin{array}{l}\text { Incremental } \\
\text { Fit Index (IFI) }\end{array}$ & $\begin{array}{l}>0,90 \\
\text { Byrne (1998) }\end{array}$ & 0.702 & Moderafit \\
\hline $\begin{array}{l}\text { Relative Fit } \\
\text { Index (RFI) }\end{array}$ & $0-1$ & 0.592 & Fit \\
\hline $\begin{array}{l}\text { Goodness of } \\
\text { Fit Index } \\
(\mathrm{GFI})\end{array}$ & $>0,90$ & 0.744 & Moderafit \\
\hline $\begin{array}{l}\text { Adjusted } \\
\text { Goodness of } \\
\text { Fit Index } \\
(\text { AGFI) } \\
\end{array}$ & $>0,90$ & 0.643 & Moderafit \\
\hline $\begin{array}{l}\text { Parsimony } \\
\text { Goodness of } \\
\text { Fit Index } \\
(\mathrm{PGFI})\end{array}$ & $0-1,0$ & 0.533 & Fit \\
\hline
\end{tabular}

Sumber: Ghozali (2010), output Amos (2020)

This fit test measures how close the implied covariance matrix (covariance matrix prediction results) and sample covariance matrix (covariance matrix of the sample data). In practice, the P-value is expected to be greater than 0.05 so that $\mathrm{H} 0$ can be accepted which means that the model is good. Chi-square test is very sensitive to data size. Yamin and Kurniawan (2009) recommend that for large sample sizes (more than 200), this test tends to reject H0. On the other hand, for small sample sizes (less than 100), this test tends to accept H0. Therefore, the data sample size that is recommended to be tested in the Chi-square test is the data sample ranges from $100-200$. The probability of the Chi-square value is $0.000>0.5$ so that there is a match between the implied covariance matrix (covariance matrix predicted results) and sample covariance matrix (covariance matrix of the sample data).The GFI measure is basically a measure of the ability of a model to 
explain the diversity of data. The GFI value ranges from $0-1$. In fact, there are no standard criteria for a good GFI score limit. However, it can be concluded that a good model is a model that has a GFI value close to 1 . In practice, many researchers use a minimum limit of 0.9 . The GFI value in the SEM analysis of 0.919 exceeds the number 0.9 or is located between $0-1$ so that the ability of a model to explain the diversity of data is very good/fit.

RMSEA is a measure of the average difference per degree of freedom expected in the population. RMSEA value $<0.08$ is good fit, while RMSEA value $<0.05$ is close fit. The RMSEA value in this study is 0.067 , so the model is said to be good/fit. NCP is expressed in terms of Chi-square re-specification. The assessment is based on comparison with other models. The smaller the value, the better. The NCP value is lower than the Cci-square value, so the model is good.Convergent validity test is obtained from the measurement data of each variable model (measurement model), this test is conducted to determine the validity of each estimated indicator, by measuring the dimensions of the concepts tested in the study. If the indicator has a nadir (critical ratio) that is greater than twice the error (standard error), it indicates that the indicator has measured what it should have measured in the model presented by Wijaya (2011). Convergent validity can be assessed by determining whether each estimated indicator validly measures the dimensions of the concept being tested. Based on table 4.22, it is known that the nadir value (critical ratio) for all existing indicators is greater than twice the standard error (standard error), which means that all items in this study are valid for each research variable. The following are the results of convergent validity testing. The results of the loading factor test are known that all variables exceed the loading factor by 0.5 so that it can be believed that all variables are eligible for further analysis.

Tabel 4.23 Hasil estimasi C.R (Critical Ratio) dan P-Value

\begin{tabular}{|lll|lllll|}
\hline & & & Estimate & S.E. & C.R. & P & Label \\
\hline KE & $<---$ & JD &, 355 &, 068 & 5,181 & $* * *$ & par_12 \\
KE & $<---$ & KL &, 694 &, 122 & 5,698 & $* * *$ & par_13 \\
KE & $<---$ & KF &, 421 &, 082 & 5,101 & $* * *$ & par_14 \\
KI & $<---$ & KE &, 586 &, 144 & 4,060 & $* * *$ & par_11 \\
KI & $<---$ & KL &, 151 &, 111 & 1,360 &, 174 & par_15 \\
KI & $<---$ & KF &, 185 &, 080 & 2,313 &, 021 & par_16 \\
\hline
\end{tabular}

Sumber : Lampiran AMOS 20 (2020)

Causality relationship with SB strategy. Critical probability causality test The causality test shows that almost all variables have a causal relationship, except between business competition and the SB strategy which does not have a ratio that has three asterisks, which can be presented in the following explanation:

1. There is a causal relationship between the jod description and the performance of bamboo SMEs. The critical value of 5.181 is twice as large as the standard error value and the probability value (p) which has an asterisk which means it is significant.

2. There is a causal relationship between SME policies and the performance of bamboo SMEs. The critical value of 5.698 is twice as large as the standard error value and the probability value (p) which has an asterisk which means it is significant.

3. There is a causal relationship between the strategy canvas and the performance of bamboo SMEs. The critical value of 5.101 is twice as large as the standard error and the probability value (p) which has an asterisk which means it is significant.

4. There is a causal relationship between the SME policy and the SB strategy. The critical value of 1.360 is twice as large as the standard error and the probability value (p) which has an asterisk which means it is significant. 
5. There is a causal relationship between the strategy canvas and the SB strategy. The critical value of 2.313 is twice as large as the standard error value and the probability value (p) which has an asterisk which means it is significant.

6. There is a causal relationship between the performance of bamboo SMEs and the SB strategy. The critical value of 4.060 is twice as large as the standard error value and the probability value (p) which has an asterisk which means it is significant.

The results of the indirect effect in the table above can be described as follows:

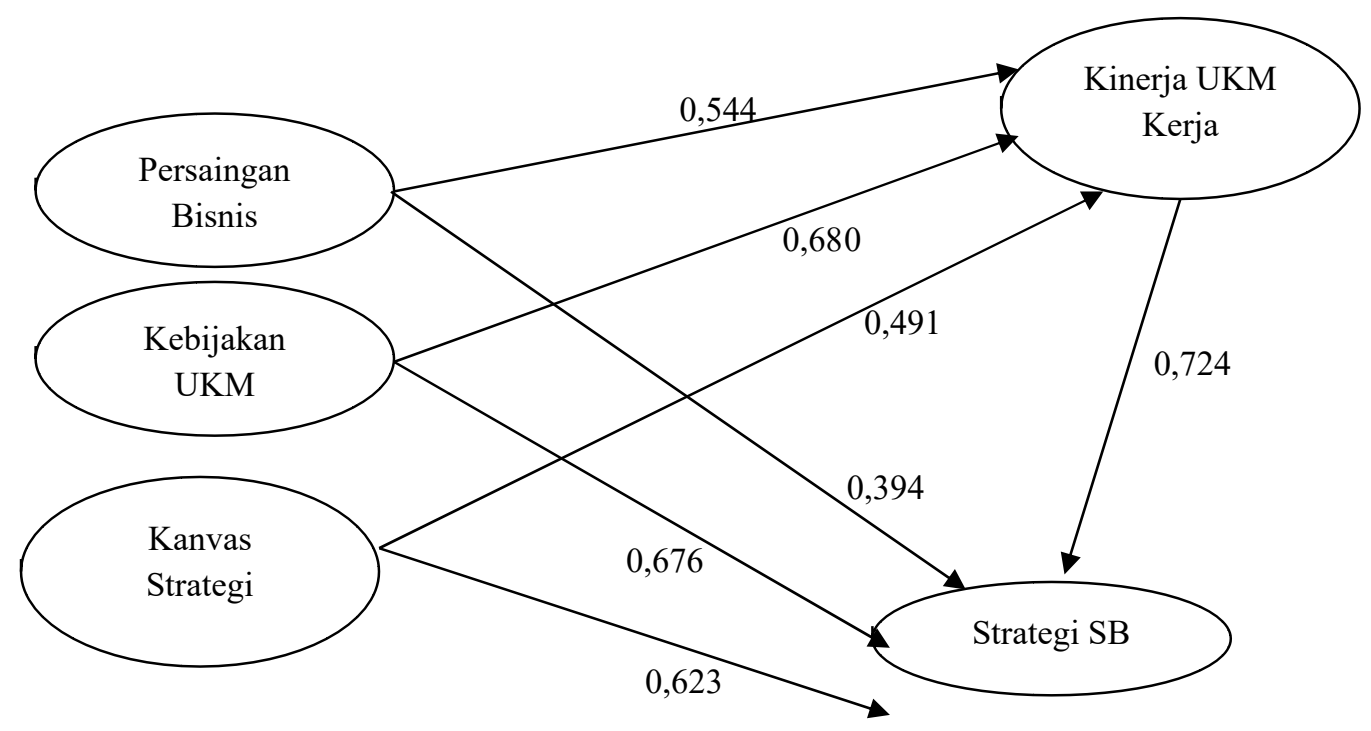

Fig 2. Total Effect

The performance of bamboo SMEs does not mediate the relationship between business competition to the SB strategy with a value of X1-Y1 $=0.544, \mathrm{Y} 1-\mathrm{Y} 2=0.724, \mathrm{Y} 2=0.544 \times 0.724=0.393>0.544$. b. The performance of bamboo SMEs does not mediate the relationship between SME policies and SB strategy with a value of $\mathrm{X} 2-\mathrm{Y} 1=0.680, \mathrm{Y} 1-\mathrm{Y} 2=0.724, \mathrm{Y} 2=0.680 \times 0.724=0.492>0.680$. The performance of bamboo SMEs does not mediate the relationship between the strategy canvas to the SB strategy with a value of $\mathrm{X} 3-\mathrm{Y} 1=0.491, \mathrm{Y} 1-\mathrm{Y} 2=0.724, \mathrm{Y} 2=0.491 \times 0.724=0.355>0.491$. Based on the picture above, it is known that all exogenous variables affect the total endogenous.

The results of the total influence show that the biggest influence on the performance of bamboo SMEs is the SME policy of 0.680, while the biggest influence on the SB strategy is the performance of bamboo SMEs of 0.724 . To find out the results of hypothesis testing, it is done by looking at the probability value (probability) or by looking at the significance of the relationship between each research variable. The criteria are if $\mathrm{p}<0.05$ then the relationship between variables is significant and can be analyzed further, and vice versa. Therefore, by looking at the probability number (p) at the output of the entire path, it shows a significant value at the $5 \%$ level or the standardize value must be greater than $1.96(>1.96)$. (If you use the comparison value of the t-count value with the $t$-table, it means that the $t$-count value is above 1.96 or $>1.96$ or the t-count is greater than t-table). AMOS 22 can set criteria for acceptance and rejection of the hypothesis as follows:

If $\mathrm{P}>0.05$ then $\mathrm{H} 0$ is accepted (not significant)

If $\mathrm{P}<0.05$ then $\mathrm{H} 0$ is rejected (significant) (Santoso, 2007)

The hypothesis in this study is divided into 10 (ten) tests, namely:

It is suspected that business competition affects the performance factors of bamboo SMEs in Binjai City. It is suspected that business competition affects SB strategy factors in Binjai City 11. It is suspected that the quality of human resources has an effect on the performance factors of bamboo SMEs in Binjai City It is suspected that the quality of human resources influences the SB Strategy factor in Binjai City. It is suspected that the strategy canvas has an effect on the performance factors of bamboo SMEs in Binjai City. It is suspected that the strategy canvas has an effect on the SB strategy factors in Binjai City. It is suspected 
that the performance of bamboo SMEs affects the SB strategy factors in Binjai City. It is suspected that business competition affects the performance of bamboo SMEs through the SB strategy in Binjai City. It is suspected that the quality of human resources affects the performance of bamboo SMEs through the SB strategy in Binjai City. It is suspected that the strategy canvas has an effect on the performance of bamboo SMEs through the SB strategy in Binjai City.

Tabel 4.27 Hasil estimasi C.R (Critical Ratio) dan P-Value

\begin{tabular}{|lll|lllll|}
\hline & & & Estimate & S.E. & C.R. & P & Label \\
\hline KE & $<---$ & JD &, 355 &, 068 & 5,181 & $* * *$ & par_12 \\
KE & $<---$ & KL &, 694 &, 122 & 5,698 & $* * *$ & par_13 \\
KE & $<---$ & KF &, 421 &, 082 & 5,101 & $* * *$ & par_14 \\
KI & $<---$ & KE &, 586 &, 144 & 4,060 & $* * *$ & par_11 \\
KI & $<---$ & KL &, 151 &, 111 & 1,360 &, 174 & par_15 \\
KI & $<---$ & KF &, 185 &, 080 & 2,313 &, 021 & par_16 \\
JD3 & $<---$ & JD & 1,000 & & & & \\
JD2 & $<---$ & JD & 1,447 &, 212 & 6,830 & $* * *$ & par_1 \\
JD1 & $<---$ & JD & 1,122 &, 172 & 6,518 & $* * *$ & par_2 \\
KL3 & $<---$ & KL & 1,000 & & & & \\
KL2 & $<---$ & KL & 1,463 &, 210 & 6,964 & $* * *$ & par_3 \\
KL1 & $<---$ & KL & 1,941 &, 272 & 7,131 & $* * *$ & par_4 \\
KF3 & $<---$ & KF & 1,000 & & & & \\
KF2 & $<---$ & KF & 1,489 &, 193 & 7,725 & $* * *$ & par_5 \\
KF1 & $<---$ & KF & 1,440 &, 197 & 7,320 & $* * *$ & par_6 \\
KE3 & $<---$ & KE & 1,000 & & & & \\
KE2 & $<---$ & KE & 1,194 &, 165 & 7,224 & $* * *$ & par_7 \\
KE1 & $<---$ & KE & 1,017 &, 159 & 6,385 & $* * *$ & par_8 \\
KI1 & $<---$ & KI & 1,000 & & & & \\
KI2 & $<---$ & KI & 1,332 &, 207 & 6,439 & $* * *$ & par_9 \\
KI3 & $<---$ & KI & 1,057 &, 183 & 5,763 & $* * *$ & par_10 \\
\hline Lampiran & Amos & & & & &
\end{tabular}

Sumber : Lampiran Amos 20 (2020)

There is a significant effect of business competition on the performance of bamboo SMEs in Observation, where the probability value has three stars. There is a significant effect of SME policy on the performance of bamboo SMEs in Observation, where the probability value has three stars. There is a significant effect of the strategy canvas on the performance of bamboo SMEs on observation, where the probability value has three stars. There is an insignificant effect of SME policy on SB strategy in Observation, where the probability value is $0.174>0.05$ so it is known that SME policy does not significantly affect SB strategy. There is an insignificant effect of the strategy canvas on the SB strategy on Observation, where the probability value is $0.021>0.05$ so it is known that the strategy canvas does not significantly affect the SB strategy. There is a significant effect of the performance of bamboo SMEs on the SB Strategy in Observation, where the probability value has three stars.

\section{CONCLUTION}

The competitive strategy used by the Small and Medium Shell Industry in Binjai City at this time is to identify the competitive factors in the industry which consist of product uniqueness, a touch of art, done in detail, proximity to sources of raw materials, strategic location, availability of labor, Creativity, Prices are not fixed on market prices, Can be used as souvenirs, Skills and skills of employees, Attractiveness and impact after participating in exhibitions, Sensitivity to market choices, Organizational commitment, Work environment, Availability of online order facilities, Experience and managerial skills, Product orders completed on time. 


\section{REFERENCES}

[1] Affif, Faisal, (2012), "Blue Ocean Strategy dan Ekonomi Kreatif”, Rangkaian Kolom Kluster I, Jakarta: Binus University.

[2] Badan Pusat Statistik. 2017. Jumlah Perusahaan Industri Mikro dan Kecil Menurut Provinsi 2013-2015.

[3] David, Fred R. (2006). Strategic Management Concepts \&Cases 9th ed. New Jersey: Prentice Hall

[4] Hermawan, Aj dan Rachel Jessica Pravitasari. 2013. Business Model Canvas (Kanvas Model Bisnis). (Retrified from akselerasi.id/media/Materi_13_-_Business_Model_Canvas.pdf/ 15-02-2015)

[5] Kim, W Chan dan Renée Mauborgne. (2005). Blue Ocean Strategy (Strategi Samudera Biru) Ciptakan Ruang Pasar Tanpa Pesaing dan Biarkan Kompetisi Tidak Lagi Relevan. PT. Serambi Ilmu Semesta. Jakarta

[6] Lasher, R Lemuel (2004). Blue Ocean Strategy. CSC World. New York

[7] Ostewalder, Alexander dan Pigneur, Yves. 2010. Business Model Generation. New Jersey: John Wiley \& Sons, Inc.

[8] Sito Vera Sylvia Saragi (2017). Strategi Bisnis Model Dengan Pendekatan Business Model Canvas (Studi Kasus Di Industri Kecil Dan Menengah (Ikm) Bir Pletok Bu Lina Di Kelurahan Ciracas, Jakarta Timur). Journal of Economics and Business Aseanomics (JEBA) Volume 2 No. 1, Januari - Juni 2017

[9] David, Fred R. (2006). Strategic Management Concepts \& Cases 9th ed. New Jersey: Prentice Hall

[10] Kim, W Chan dan Renée Mauborgne. (2005). Blue Ocean Strategy (Strategi Samudera Biru) Ciptakan Ruang Pasar Tanpa Pesaing dan Biarkan Kompetisi Tidak Lagi Relevan. PT. Serambi Ilmu Semesta. Jakarta

[11] Kim, Chan W. \& Mauborgne, Renee. (2005). Value Innovation : A Leap Into The Blue Ocean. Retrieved December 1, 2016

[12] Lasher, R Lemuel (2004). Blue Ocean Strategy. CSC World. New York

[13] Moleong, L.J. (2011). Metodologi Penelitian Kualitatif (edisi revisi). Bandung: PT. Remaja Rosdakarya. 